\title{
Effects of Almond Milk on Body Measurements and Blood Pressure
}

\author{
Jozaa Zaidan Al Tamimi \\ Department of Nutrition and Food Science, College of Home Economics, Princess Nourah Bint Abdulrahman \\ University, Riyadh, Saudi Arabia \\ Email: jzaltamimi@pnu.edu.sa
}

Received 21 April 2016; accepted 27 May 2016; published 30 May 2016

Copyright $@ 2016$ by author and Scientific Research Publishing Inc.

This work is licensed under the Creative Commons Attribution International License (CC BY).

http://creativecommons.org/licenses/by/4.0/

(c) (i) Open Access

\begin{abstract}
In recent years, the demand for almond milk and its sales has increased owing to consumers' perceptions about its health benefits. Hence, we sought to measure the effect of almond milk on body measurements such as body weight, body mass index and waist and hip circumference, in addition to diastolic and systolic blood pressures. Thirty volunteers of both sexes participated in the study, with a mean age of $23.27 \pm 6.20$ years. The study was conducted over 4 weeks, and the results showed that daily substitution of one serving of dairy product with one cup (240 ML) of almond milk significantly decreased body weight, body mass index and waist and hip circumference, However, no effects were observed on blood pressures.
\end{abstract}

\section{Keywords}

Almond Milk, Weight, Body Mass Index, Waist Circumference, Hip Circumference, Diastolic and Systolic Blood Pressure

\section{Introduction}

Almond (Prunus amygdalus) [1] is a fruit from the almond tree, which is a deciduous tree reaching about 4 - 5 $\mathrm{M}$ in height. The young twigs are green at first, becoming purplish when exposed to sunlight and then grey in the second year [2]. The flowers appear before the leaves in early spring and are white to pale pink [3] [4]. Almond grows best in Mediterranean climates, which have warm, dry summers and mild, wet winters. The optimal temperature for its growth is between $15^{\circ} \mathrm{C}$ and $30^{\circ} \mathrm{C}\left(59^{\circ} \mathrm{F}\right.$ and $86^{\circ} \mathrm{F}$, respectively) [5]. Almond crop harvest begins in the third year of its life [4]. The almond tree has been cultivated since ancient times (450 BC). It is prevalent on the shores of the Mediterranean, the Middle East and eastward as far as the Indus River in Pakistan. It is found in Iran, India, Afghanistan, Pakistan, northern Africa and southern Europe. It also grows in other parts of the world, notably in California, USA [6]. 
In addition to its low content of saturated fats and lack of cholesterol, almonds are known for their nutritional content, which is high in protein, fibre, unsaturated fatty acids, tocopherol and many vitamins and minerals [7]. Ros reported that almonds are rich in alpha-tocopherol and antioxidants, which are concentrated in the shell. Thus, shelling almonds leads to the loss of $25 \%-50 \%$ of antioxidants [8]. One hundred grams of almonds contain 579 calories, 21.15 g protein, $49.93 \mathrm{~g}$ fat, $21.55 \mathrm{~g}$ carbohydrates, $12.5 \mathrm{~g}$ fibre, $269 \mathrm{mg}$ calcium, $270 \mathrm{mg}$ magnesium, $481 \mathrm{mg}$ phosphorus, $733 \mathrm{mg}$ potassium, $1.138 \mathrm{mg}$ riboflavin, $3.618 \mathrm{mg}$ niacin and $25.63 \mathrm{mg}$ alphatocopherol [9]. Maguire et al., found that the percentage of unsaturated fatty acids was $91.6 \%$ of the total amount of fats [10].

Almonds have high nutritional value and many health benefits. Berryman et al., found that consuming $42.5 \mathrm{~g}$ of almonds per day maintains the levels of high-density lipoprotein cholesterol, lowers the levels of low-density lipoprotein cholesterol and reduces central obesity [11]. Moreover, the consumption of almonds reduces the risk of heart diseases [12], increases the plasma concentration of polyphenols, raises the total antioxidant potential in the plasma, and reduces lipid peroxidation [13]. Furthermore, the consumption of almonds reduces the risk of colon cancer [14].

Owing to the nutritional value and health benefits of almonds, they are now used in the production of many nutritious products such as beverages, pasta, cream, snacks and bakery products [15]. The demand for plantbased drinks has increased because of the prevalence of allergies to animal milk protein and there is much interest in soybean and almond milk because of their nutritional value [16]. Almond milk is one of the most commonly sold plant-based milk products and its popularity has been attributed to various reasons, most important being the consumers' perceptions about it, its health benefits, and the many brands and flavours available in the market [17]. Almond milk has now become the most popular plant-based milk product in the USA and its sales have overtaken that of soybean milk, representing $4.1 \%$ of total milk sales [18].

Almond milk contains a high percentage of monounsaturated fatty acids. Moreover, it has a balanced composition in terms of proteins, fats, fibre and vitamins and minerals and does not contain lactose [19]. Thus, it is suitable for those who suffer from lactose and milk protein intolerance [20].

Almond milk has become more popular in recent years because of its low calorie content and nutritional benefits. The objective of the present study is to evaluate the effects of almond milk on body measurements and blood pressure.

\section{Methods}

\subsection{Preparation of Almond Milk}

Almonds were obtained from the local markets in Riyadh, Saudi Arabia. Almond milk was prepared following the traditional method of soaking $250 \mathrm{~g}$ of almonds in water for $12-24 \mathrm{~h}$ at room temperature. The soaking water was then discarded and the almonds were put in an electric blender with $1 \mathrm{~L}$ of water and blended thoroughly for 2 - 4 min till the milk is completely smooth and no chunks of nuts remain. The mixture was strained with a fine strainer lined using a thin fabric muslin to remove the shells and the milk was stored in the refrigerator on $40^{\circ} \mathrm{F}$ for cooling prior to consumption.

\subsection{Study Sample}

The study was conducted with 30 volunteers randomly of both sexes (6 males and 24 females) who are ready to join the study sample throughout the study period. The mean age was $23.27 \pm 6.20$ years and no one suffered from chronic diseases. All volunteers gave verbal consent to participate in the study. The study was conducted in accordance with the requirements of scientific research of the Department of Nutrition and Food Sciences at Princess Nourah Bint Abdul Rahman University in 2014.

\subsection{Data Collection}

Participants' anthropometric measurements and weights were measured to the nearest half kilogram using a physician scale, stainless steel, weigh beam $180 \mathrm{~kg} \times 100 \mathrm{~g}$, height rod, Detecto scale company, (USA) balance, and their height was measured to the nearest half centimetre. Furthermore, the participants' waist and hip circumferences were measured to the nearest millimetre using a metric tape. The participants' body mass index was calculated using the following formula: 
Body mass index $=$ weight in kilograms/height in metres squared [21]. The patients' blood pressure was measured using a blood pressure monitor from Omron M6 ACHEM-7322-E (Matsusaka Mie, Japan).

Participants in the study were asked to substitute only one serving of their daily consumption of dairy products with almond milk, which was prepared daily, without making any other changes to their usual diet. The participants' body measurements and blood pressure levels were also taken 2 weeks after the start of the experiment. The experiment was conducted over 4 weeks, after which the body measurements and blood pressure were taken for the third time.

\subsection{Data Analysis}

The data were summarised using the Statistical Package for Social Sciences (SPSS Inc., Chicago, IL, USA) version 17 for calculating arithmetic means and the standard deviation, conducting statistical analyses such as the paired sample $t$-tests and drawing graphs.

\section{Results}

Table 1 shows the effects of almond milk on the studied body measurements; the table shows a decrease in the mean weight and a consequent reduction of the body mass index over the 4 weeks period. In addition, the waist and hip circumference decreased. The mean body mass index at the beginning of the experiment was $23.44 \pm$ $3.43 \mathrm{~kg} / \mathrm{m}^{2}$. By the end of the second week, this dropped to $23.00 \pm 3.41 \mathrm{~kg} / \mathrm{m}^{2}$, which fell to $22.71 \pm 3.42 \mathrm{~kg} / \mathrm{m}^{2}$ by the end of the study. The mean waist circumference at the beginning of the experiment was $67.83 \pm 15.62 \mathrm{~cm}$, which fell to $66.21 \pm 16.64 \mathrm{~cm}$ by the end of the study. Similar results were found for the mean hip circumference, which was $76.17 \pm 4.84 \mathrm{~cm}$ at the beginning of the experiment, and $73.13 \pm 5.18 \mathrm{~cm}$ at the end of the experiment. Table 1 also shows that the effect of almond milk on the body measurements was statistically significant after 2 weeks $(p \leq 0.000)$. Furthermore, this statistically significant effect continued to the end of the experiment (end of the fourth week).

Figure 1 shows the changes in the mean weight, body mass index and waist and hip circumferences over the duration of the study. A decrease can be seen in the mean body measurements during the study period.

The systolic and diastolic blood pressures were not affected by the daily consumption of almond milk and no statistically significant effects were observed during the study period (Table 2).

\section{Discussion}

The results of the present study showed that the daily substitution of one serving of dairy product with one cup of almond milk caused statistically significant decreases in weight, body mass index and waist and hip circumferences over the study period. This may be attributed to the low calorie content of almond milk compared with that of cow milk (3.7\% fat) because one cup of unsweetened almond milk contains 39 calories in contrast to the 156 calories in one cup of cow milk [9].

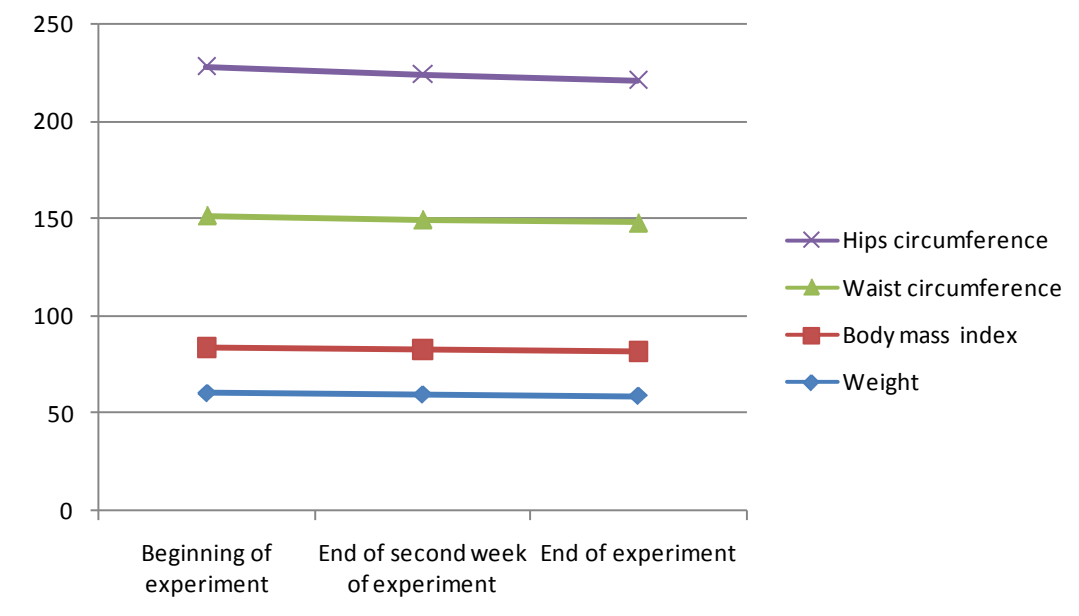

Figure 1. Effect of almond milk on mean body measurements during the experiment. 
Table 1. Effect of almond milk on the participants’ body measurements.

\begin{tabular}{|c|c|c|c|c|c|c|}
\hline & Variable & Mean \pm SD & $\begin{array}{c}\text { Correlation } \\
\text { coefficient }\end{array}$ & T-value & DF & $p$-value \\
\hline \multirow{3}{*}{ Weight in $\mathrm{kg}$} & $\begin{array}{l}\text { At the beginning of the first week of the } \\
\text { experiment }\end{array}$ & $60.84 \pm 11.62$ & & & & \\
\hline & End of the second week of the experiment & ${ }^{*} 59.73 \pm 11.69$ & 0.997 & 6.868 & \multirow{2}{*}{29} & 0.00 \\
\hline & End of the fourth week of the experiment & ${ }^{*} 59.00 \pm 11.78$ & 0.992 & 6.922 & & 0.00 \\
\hline \multirow{3}{*}{$\begin{array}{l}\text { Body mass index in } \\
\mathrm{kg} / \mathrm{m}^{2}\end{array}$} & Beginning of the first week of the experiment & $23.44 \pm 3.43$ & & & & \\
\hline & End of the second week of the experiment & ${ }^{*} 23.00 \pm 3.41$ & 0.995 & 6.831 & \multirow{2}{*}{29} & 0.00 \\
\hline & End of the fourth week of the experiment & ${ }^{*} 22.71 \pm 3.42$ & 0.986 & 6.855 & & 0.00 \\
\hline \multirow{3}{*}{$\begin{array}{l}\text { Waist circumference } \\
\text { in } \mathrm{cm}\end{array}$} & Beginning of the first week of the experiment & $67.83 \pm 15.62$ & & & & \\
\hline & End of the second week of the experiment & ${ }^{*} 66.89 \pm 16.21$ & 0.999 & 5.363 & \multirow{2}{*}{29} & 0.00 \\
\hline & End of the fourth week of the experiment & ${ }^{*} 66.21 \pm 16.64$ & 0.997 & 5.513 & & 0.00 \\
\hline \multirow{3}{*}{$\begin{array}{l}\text { Hip circumference } \\
\text { in } \mathrm{cm}\end{array}$} & Beginning of the first week of the experiment & $76.17 \pm 4.84$ & & & & \\
\hline & End of the second week of the experiment & ${ }^{*} 74.0 \pm 5.37$ & 0.981 & 7.254 & \multirow{2}{*}{14} & 0.00 \\
\hline & End of the fourth week of the experiment & ${ }^{*} 73.13 \pm 5.18$ & 0.975 & 10.023 & & 0.00 \\
\hline
\end{tabular}

* Statistically significant at $p \leq 0.000 ; \mathrm{SD}=$ std. deviation; $\mathrm{DF}=$ degrees of freedom.

Table 2. Effect of almond milk on the participants' blood pressure.

\begin{tabular}{cccccc}
\hline & Variable & Mean \pm SD & $\begin{array}{c}\text { Correlation } \\
\text { coefficient }\end{array}$ & T-value & DF value \\
& Beginning of the first week of the experiment & $119.60 \pm 9.27$ & & 0.762 & $1.762-$ \\
$\begin{array}{c}\text { Systolic blood } \\
\text { pressure in mmHg }\end{array}$ & End of the second week of the experiment & $121.53 \pm 7.39$ & 0.089 \\
& End of the fourth week of the experiment & $120.03 \pm 5.10$ & 0.570 & $0.32-$ \\
\hline $\begin{array}{c}\text { Diastolic blood } \\
\text { pressure in mmHg }\end{array}$ & Eeginning of the first week of the experiment & $74.77 \pm 11.25$ & 0.842 & $0.811-$ \\
\hline
\end{tabular}

* Statistically significant at $p \leq 0.000$; SD = std. deviation; $\mathrm{DF}=$ degrees of freedom.

In a study have noted that almond consumption does not lead to weight gain when added to the diet, when included in a low calorie diet, it can enhance weight loss. Furthermore, almond is characterised by a low sugar indicator [22].

In a study by Hollis and Mattes, participants were asked to add almonds to their normal diet; the authors found that the consumption of almonds did not affect the participants' weight, despite the increase in calories. This makes almond a good alternative as a snack, owing to its ability to curb hunger and decrease the desire to eat larger meals. This may be because almonds contain monounsaturated fats, protein and fibre which contribute to feelings of satiety [23].

In a study by Tan and Mattes, although the participants were asked to add almonds to their normal daily diet with main meals or as snacks, no statistically significant effects were observed on the weight, body mass index or blood pressure [24] and Fraser, et al., found similar results [25].

In this study there was no addition to the participants' normal diet; there was only substitution with a product that had a lower calorie content, which led to the reduction in weight. Moreover, the fats in almond milk, which amount to $2.88 \mathrm{~g}$, are mostly monounsaturated (1.86 g), with the remaining amount being polyunsaturated fat [9].

Many studies have shown that polyunsaturated fat can promote weight loss. A study conducted in 2012 by the Missouri University of Science and Technology indicated that when given almond oil, improvements were observed in normal weight and obese lab rats in terms of insulin sensitivity and glucose tolerance. Furthermore, 
their weight remarkably decreased [26].

Mandalari, et al., noted the health and nutritional benefits of almond fats. They reported that these fats improve the function of the digestive system and raise the levels of beneficial bacteria in the digestive system. Interestingly, these characteristics were observed only when finely ground almond was used and not when defatted almonds were used [27]. In addition, Gadgil et al., found that insulin sensitivity improves with the adoption of a diet that is rich in unsaturated fatty acids [28].

Despite the fact that almond milk is a good source of alpha-tocopherol, which has an important role in improving the health of blood vessels and preventing blood circulation diseases, the present study did not show any changes in the participants' systolic and diastolic blood pressures. Choudhury, et al., found that daily consumption of $50 \mathrm{~g}$ of almonds by healthy adults for 4 weeks led to a decrease in the mean diastolic blood pressure. However, no changes occurred in the blood pressure of adults at risk for hypertension. The reason for the lack of effect on blood pressure may be that the amount of alpha-tocopherol in 1 cup of almond milk is $7.36 \mathrm{mg}$. In contrast, Choudhury et al., reported $12 \mathrm{mg}$ of alpha-tocopherol in $50 \mathrm{~g}$ of almonds [29].

\section{Conclusion}

The present study revealed the effects of daily consumption of almond milk on body measurements. From the results of the study, we recommend further long-term research, especially on obese individuals and those with indications of metabolic syndrome, in addition to further studies on the long-term effect of almond milk on blood pressure.

\section{Acknowledgements}

The researcher would like to express sincere gratitude to the students Haleemah Mohammed Sharahili and Norah Saleh Al Rashidi for taking part in data collection and conducting the experiments on the participants.

\section{References}

[1] Barceloux, D.G. (2008) Medical Toxicology of Natural Substances: Foods, Fungi, Medicinal Herbs, Plants, and Venomous Animals. John Wiley \& Sons. http://dx.doi.org/10.1002/9780470330319

[2] Bailey, L.H. and Bailey, L.H. (1976) Hortus Third: A Concise Dictionary of Plant Cultivated in US and Canada (No. 582.03/B155). MacMilan Publishing Co. Inc.

[3] Keith, R. (1999) Collins Wildlife Trust Guide Trees: A Photographic Guide to the Trees of Britain and Europe. Harper Collins, London.

[4] Griffiths, M.D. and Huxley, A.J. (1992) The New Royal Horticultural Society Dictionary of Gardening. Macmillan Press, London.

[5] (2011) “Almond”. Plant Village, The Huck Institutes of the Life Sciences, Pennsylvania State University. https://www.plantvillage.org/en/topics/almond/diseases_and_pests_description_uses_propagation

[6] Micke, W.C. (1996) Almond Production Manual. Oakland: University of California (System). Division of Agriculture and Natural Resources. UCANR Publications 3364.

[7] Miraliakbari, H. and Shahidi, F. (2008) Lipid Class Compositions, Tocopherols and Sterols of Tree Nut Oils Extracted with Different Solvents. Journal of Food Lipids, 15, 81-96. http://dx.doi.org/10.1111/j.1745-4522.2007.00104.x

[8] Ros, E. (2010) Health Benefits of Nut Consumption. Nutrients, 2, 652-682. http://dx.doi.org/10.3390/nu2070652

[9] United States Department of Agriculture (2016) Nutrient Database for Standard Reference Release 28. http://ndb.nal.usda.gov/ndb/foods/show/3635?manu=\&fgcd

[10] Maguire, L.S., O’Sullivan, S.M., Galvin, K., O’Connor, T.P. and O’Brien, N.M. (2009) Fatty Acid Profile, Tocopherol, Squalene and Phytosterol Content of Walnuts, Almonds, Peanuts, Hazelnuts and the Macadamia Nut. International Journal of Food Sciences and Nutrition, 55, 171-178. http://dx.doi.org/10.1080/09637480410001725175

[11] Berryman, C.E., West, S.G., Fleming, J.A., Bordi, P.L. and KrisEtherton, P.M. (2015) Effects of Daily Almond Consumption on Cardiometabolic Risk and Abdominal Adiposity in Healthy Adults with Elevated Ldlcholesterol: A Randomized Controlled Trial. Journal of the American Heart Association, 4, e000993. http://dx.doi.org/10.1161/JAHA.114.000993

[12] Nishi, S., Kendall, C.W., Gascoyne, A.M., Bazinet, R.P., Bashyam, B., Lapsley, K.G., Augustin, L.S., Sievenpiper, J.L. and Jenkins, D.J. (2014) Effect of Almond Consumption on the Serum Fatty Acid Profile: A Dose-Response Study. British Journal of Nutrition, 112, 1137-1146. http://dx.doi.org/10.1017/S0007114514001640 
[13] Torabian, S., Haddad, E., Rajaram, S., Banta, J. and Sabate, J. (2009) Acute Effect of Nut Consumption on Plasma Total Polyphenols, Antioxidant Capacity and Lipid Peroxidation. Journal of Human Nutrition and Dietetics, 22, 64-71. http://dx.doi.org/10.1111/j.1365-277X.2008.00923.x

[14] Davis, P.A. and Iwahashi, C.K. (2001) Whole Almonds and Almond Fractions Reduce Aberrant Crypt Foci in a Rat Model of Colon Carcinogenesis. Cancer Letters, 165, 27-33. http://dx.doi.org/10.1016/S0304-3835(01)00425-6

[15] Gallier, S., Gordon, K.C. and Singh, H. (2012) Chemical and Structural Characterisation of Almond Oil Bodies and Bovine Milk Fat Globules. Food Chemistry, 132, 1996-2006. http://dx.doi.org/10.1016/j.foodchem.2011.12.038

[16] Valencia-Flores, D.C., Hernández-Herrero, M., Guamis, B. and Ferragut, V. (2013) Comparing the Effects of UltraHigh-Pressure Homogenization and Conventional Thermal Treatments on the Microbiological, Physical, and Chemical Quality of Almond Beverages. Journal of Food Science, 78, E199-E205. http://dx.doi.org/10.1111/1750-3841.12029

[17] Van Allen, J. (2014) Got Milk? From a Cow or a Plant? The Washington Post. http://www.washingtonpost.com/news/to-your-health/wp/2014/06/10/got-milk-from-a-cow-or-a-plant/

[18] Ungerleider, N. (2014) Demand for Almond Milk Is Growing, but Is It Bad for the Planet? http://www.kcet.org/living/food/the-nosh/demand-for-almond-milk-is-soaring-but-is-it-bad-for-the-planet.html

[19] Jalali-Khanabadi, B.A., Mozaffari-Khosravi, H. and Parsaeyan, N. (2010) Effects of Almond Dietary Supplementation on Coronary Heart Disease Lipid Risk Factors and Serum Lipid Oxidation Parameters in Men with Mild Hyperlipidemia. The Journal of Alternative and Complementary Medicine, 16, 1279-1283. http://dx.doi.org/10.1089/acm.2009.0693

[20] Dhakal, S., Liu, C., Zhang, Y., Roux, K.H., Sathe, S.K. and Balasubramaniam, V.M. (2014) Effect of High Pressure Processing on the Immunoreactivity of Almond Milk. Food Research International, 62, 215-222. http://dx.doi.org/10.1016/j.foodres.2014.02.021

[21] Gibson, R.S. (1993) Nutritional Assessment: A Laboratory Manual. Oxford University Press, New York.

[22] Chen, C.Y., Lapsley, K. and Blumberg, J. (2006) Nutrition and Health Perspective on Almonds. Journal of the Science of Food and Agriculture, 86, 2245-2250. http://dx.doi.org/10.1002/jsfa.2659

[23] Hollis, J. and Mattes, R. (2007) Effect of Chronic Consumption of Almonds on Body Weight in Healthy Humans. British Journal of Nutrition, 98, 651-656. http://dx.doi.org/10.1017/S0007114507734608

[24] Tan, S.Y. and Mattes, R.D. (2013) Appetitive, Dietary and Health Effects of Almonds Consumed with Meals or as Snacks: A Randomized, Controlled Trial. European Journal of Clinical Nutrition, 67, 1205-1214. http://dx.doi.org/10.1038/ejcn.2013.184

[25] Fraser, G.E., Bennett, H.W., Jaceldo, K.B. and Sabaté, J. (2002) Effect on Body Weight of a Free 76 Kilojoule (320 Calorie) Daily Supplement of Almonds for Six Months. Journal of the American College of Nutrition, 21, 275-283. http://dx.doi.org/10.1080/07315724.2002.10719221

[26] Ghosh, S. and Oerther, D. (2012) Tree Oil May Combat Obesity, Diabetes, S\&T Research Suggests. Missouri University of Science and Technology, The Bridge Civil, Architectural and Environmental Engineering, Vol. $29,20$. http://www.mst.edu/

[27] Mandalari, G., Nueno-Palop, C., Bisignano, G., Wickham, M.S.J. and Narbad, A. (2008) Potential Prebiotic Properties of Almond (Amygdalus communis L.) Seeds. Applied and Environmental Microbiology, 74, 4264-4270. http://dx.doi.org/10.1128/AEM.00739-08

[28] Gadgil, M.D., Appel, L.J., Yeung, E., Anderson, C.A., Sacks, F.M. and Miller, E.R. (2013) The Effects of Carbohydrate, Unsaturated Fat, and Protein Intake on Measures of Insulin Sensitivity: Results from the OmniHeart Trial. Diabetes Care, 36, 1132-1137. http://dx.doi.org/10.2337/dc12-0869

[29] Choudhury, K., Clark, J. and Griffiths, H.R. (2014) An Almond-Enriched Diet Increases Plasma $\alpha$-Tocopherol and Improves Vascular Function but Does Not Affect Oxidative Stress Markers or Lipid Levels. Free Radical Research, 48, 599-606. http://dx.doi.org/10.3109/10715762.2014.896458 